Proceedings

\title{
Influence of Meteorological Factors on Population Dynamics of Fall Armyworm, Spodoptera frugiperda, Lepidoptera: Noctuidae and its Varietal Susceptiblilty to FAW ${ }^{+}$
}

\author{
Shahbaz Ahmad * and Muhammad Arslan Ibrahim
}

Citation: Ahmad, S.; Ibrahim, M.A. Influence of Meteorological Factors on Population Dynamics of Fall Armyworm, Spodoptera frugiperda, Lepidoptera: Noctuidae and its Varietal Susceptiblilty to FAW, in Proceedings of the 1st International Electronic Conference on Entomology, 1-15 July 2021, MDPI: Basel, Switzerland, doi:10.3390/IECE-10609

Published: 6 July 2021

Publisher's Note: MDPI stays neutral with regard to jurisdictional claims in published maps and institutional affiliations.

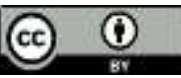

Copyright: (C) 2021 by the authors Submitted for possible open access publication under the terms and conditions of the Creative Commons Attribution (CC BY) license (http://creativecommons.org/licenses /by/4.0/).
Deaprtment of Entomology, University of the Punjab and 54590

* Correspondence: shahbaz.iags@pu.edu.pk

+ Presented at the 1st International Electronic Conference on Entomology (IECE 2021), 1-15 July 2021; Available online: https://iece.sciforum.net/.

\begin{abstract}
The invasive armyworm, Spodoptera frugiperda (J.E. Smith) (Lepidoptera: Noctuidae) is a key pest of maize that has invaded Pakistan causing severe damage and yield losses. The current investigation was directed to visualize fall armyworm infestation on eight of the different maize varieties. Correlation analysis of FAW infestation with weather factors revealed that temperature (max., mean, and min.) had a weak positive effect on fall armyworm infestation $(r=0.139, r=0.149$ and $r=$ 0.159 , respectively) while relative humidity played a weak negative $(r=-0.104)$ role in FAW population build-up. A seasonal mean infestation of the pest found maximum on Malka-16 which was statistically higher than any other variety. The lowest invasion was recorded on the P1543 Hybrid $(\mathrm{P}<0.05)$. Similarly, the infestation was significantly highest in the $1^{\text {st }}$ half of November $(\mathrm{P}<0.05)$, a decline in pest population build-up was seen in December possibly by cold weather.
\end{abstract}

Keywords: Management; MaizeSpodoptera frugiperda; yield losses

\section{Introduction}

Fall armyworm (FAW), Spodoptera frugiperda (JE Smith) (Lepidoptera: Noctuidae) is an invasive pest of maize crop. It is native to the Americas and was first reported as an aggressive pest in Africa in the tropical zones of Nigeria, in 2016 (Akutse et al 2019). Subsequently, it was spread to different parts of the African continent. It was reported that fall armyworm attacks about 350 host plant species belong to 76 plant families (Montezano et al

2018). In Pakistan, fall armyworm was reported on maize during the fall session of 2019 in Sindh province (Naeem-Ullah et al 2019). Since then, it has spread to many parts of the country causing devastation to maize production. 
In Pakistan, it has been seen from the recent invasions of fall armyworm that the crops planted by smallholders were more prone to damage. The reason is simple that they cannot afford expensive agricultural inputs. Most of the maize growers in the country are smallholders who always look for low-cost managemental practices to curb pest problems. The use of resistant varieties is an old method and is frequently adopted by smallholders (Abid et al 2019). The studies on the screening of variable varieties having different genomes against exotic pests could be an effective initiative to determine the extent of tolerance found in such varieties (Kasoma et al 2020).

The fluctuations in the population build-ups of insects are directly linked with biotic and abiotic factors that prevail in the micro and macro climates of insect pests (Kamata 2000). Insect populations do not remain the same throughout the year, they get vary with the change in environmental factors like temperature, humidity, or rainfall (Wallner 1987). The seasonal studies about population dynamics, depending on biotic or abiotic factors, provide necessary clues for the management of important crop pests (Aasman 2001). Population ecologists classify the factors, that determine the size of the population, into two major categories; density-independent factors (weather and climate) and density-dependent factors (diseases, competitions and natural enemies). Density independent factors are sometimes regarded as limiting factors while density-dependent factors are known as regulating factors since they keep the population in a narrow range and do not let the population expand freely (Britannica 2017).

The poikilothermic nature of the insects makes them highly sensitive to external temperatures. In general perception, temperature is regarded as the most significant environmental factor influencing the development, behaviour, distribution, reproduction, and survival of insects (Briere et al 1999). Temperature-dependent studies of insect pests are always very crucial in understanding the population dynamics of insects and their implementation helps in designing specific pest-control strategies (Ahmad 2016).

Another most important abiotic factor that determines insect survival is the humidity. Variation in humidity levels influences the developmental stages of insects. A high level of relative humidity (RH) could be advantageous for the survival and growth of immature stages of certain insect species ( $\mathrm{Lu} \& \mathrm{Wu} 2011$ ). A few investigations declare the higher levels of RH as a source of mortality in insects through fungal (Shipp et al 2003) or viral (Fuxa et al 1999) infections. Similarly, low RH may stop embryonic development and loss of softness in the cuticular layer (Guarneri et al 2002). The present study deals with fall armyworm population density on eight maize varieties grown under agroecological conditions of the Punjab, Pakistan and the relationship of weather conditions e.g., temperature and relative humidity against FAW population build up on eight maize varieties.

\section{Materials and Methods:}

Study site description: 
The study was conducted at Fisheries and Crop Research Station, University of the Punjab $\left(31.498356^{\circ} \mathrm{N}, 74.293647^{\circ} \mathrm{E}\right)$. The site was characterized by well-drained clay to loamy soil with a relatively leveled cropping area. In order to study the effects of abiotic factors on FAW infestation upon different varieties of maize, an experiment was conducted following the randomized complete block design (RCBD). Eight varieties including four conventional and four hybrids were cultivated and the sowing was done on the $18^{\text {th }}$ of September 2019. All of the treatments were repeated thrice and each unit plot size was maintained at $(4 \times 4.5 \mathrm{~m})$. Seeds were planted using seed driller with 6 inches plant to plant distance while row to row distance was maintained at $1 \mathrm{ft}$. The fertilizers $(\mathrm{N}, \mathrm{P}, \mathrm{K})$ were applied at the rate of $(80,46,37) \mathrm{Kg} /$ acre respectively. Irrigation and weed management practices were performed accordingly to the technical recommendations by Agriculture Punjab's Maize Production Technology.

\section{Treatment variables:}

Four conventional and four hybrid varieties were selected to screen out against FAW infestation. The seeds were purchased from a registered local seed distributor, Manga Mandi, Lahore. Before cultivation, seeds were treated with Topsin-M (70 WP) which is a fungicide and prevents fungal diseases. The description of varieties is given as:

Table 1. Treatment variables and description.

\begin{tabular}{cccc}
\hline Varieties & Treatment No. & Developed By & Maturity (in days) \\
\hline Gohar-19 & V1 & MMRI* & $95-100$ \\
\hline Pearl-2011 & V2 & MMRI & 120 \\
\hline CIMMYT Pak & V3 & MMRI & 115 \\
\hline Malka-2016 & V4 & MMRI & 100 \\
\hline Karamat Hybrid & V5 & CRCI** & 110 \\
\hline Ghouri Hybrid & V6 & CRCI & 115 \\
\hline 31P41 Hybrid & V7 & Pioneer & 100 \\
\hline P1543 Hybrid & V8 & DuPont & 113 \\
\hline $\begin{array}{l}{ }^{*} \text { MMRI= Maize and Millet Research Institute, Yousafwala, Sahiwal, Pakistan. }{ }^{* * C R C I=~ C e r e a l ~ C r o p s ~} \\
\text { Research Institute, Pir Sabaq, KPK, Pakistan. }\end{array}$ & &
\end{tabular}




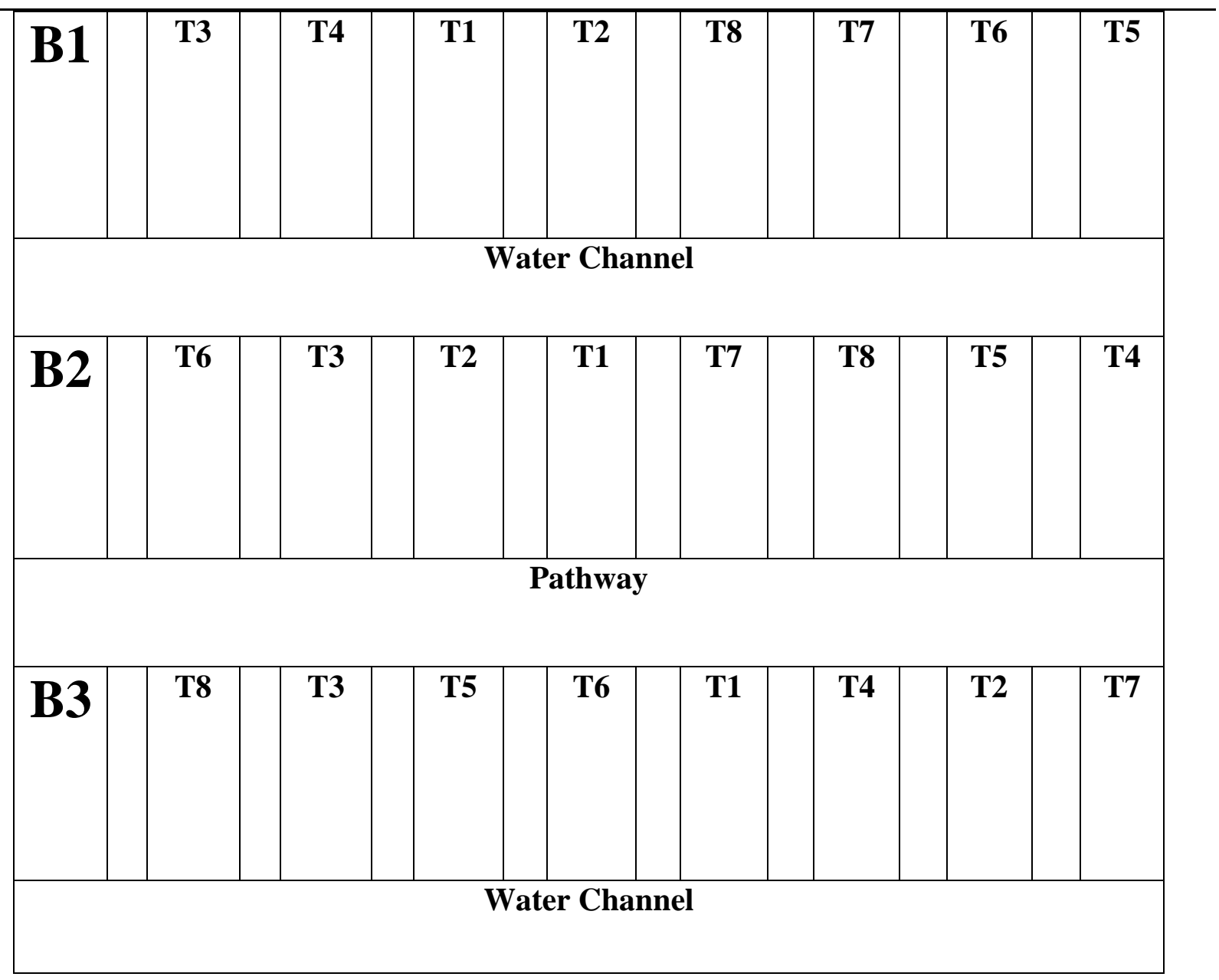

Figure 1. Field experiment design.

\section{Data Collection:}

From each of the experimental units, the data were collected from 6 different spots in a zig-zag fashion, and from each spot 10 plants were observed. Plants were inspected for the physical presence of larval form in the central whorl of the plant, egg masses, damaging signs including windowing, shot holes, lumps of frass, ragged and torn leaves. Data were taken weekly from 14-Oct-2019 to onward till the crop harvesting. To find out percentage infestation, the following formula was used as described by Mashwani et al (2011).

Percentage Infestation $=($ No. of Plants Infested $/$ Total No. of Plants Inspected) $\times 100$

The percentage infestation was calculated against each of the 10 plants from the single spot and the average of 6 different spots gave mean infestation present in a single experimental unit. 
Meteorological Data:

Data on daily temperature and relative humidity were taken from the observatory officials of the Centres for Integrated Mountain Research (CIMR) department of University of the Punjab, Lahore, Pakistan.

\section{Statistical Analysis:}

The infestation data were subjected to ANOVA (Analysis of Variance) by using software Statistics 8.1 while means were compared through Tukey's HSD test at $\mathrm{P}=0.05$. The percentage of infestation was correlated with meteorological factors i-e., temperature $\left({ }^{\circ} \mathrm{C}\right)$ and relative humidity (R.H.) (\%).

\section{Results:}

The FAW infestation recorded from different maize varieties were subjected to statistical analyses. The pest infestation remained significantly different on all eight maize varieties as given by the ANOVA (Table 2).

Table 2. Analysis of variance (ANOVA) for mean infestation.

\begin{tabular}{cccccc}
\hline S. O. V & Df & SS & MS & F & P \\
\hline W & 9 & 17681.8 & 1964.65 & & \\
\hline T & 7 & 349.2 & 49.89 & 9.04 & $0.0000^{* *}$ \\
\hline Error & 63 & 347.8 & 5.52 & & \\
Total & 79 & 18378.8 & & & \\
\hline & $* *$ Highly Significant means $(\mathrm{P}<0.05)$ & Grand mean 22.199 & CV 10.58.
\end{tabular}

Mean comparison test (HSD) explains that the maximum cumulative mean infestation was observed on Malka16 which was a conventional variety of maize, and statistically, it was different from Gohar-19, Karamat Hybrid, Pearl 2011, CIMMYT Pak, Ghouri Hybrid, 31P41 Hybrid, and P1543 Hybrid. The minimum infestation was recorded on the P1543 Hybrid of maize which showed some sort of resistance against FAW (Table 3).

Table 3. Seasonal FAW infestation on different maize varieties.

\begin{tabular}{ccc}
\hline Maize Varieties & Mean \pm S.E. & Homogenous Groups \\
\hline Malka-16 & $25.83 \pm 0.77$ & $\mathrm{~A}$ \\
\hline Gohar-19 & $23.99 \pm 0.86$ & $\mathrm{AB}$ \\
\hline Karamat Hybrid & $22.499 \pm 0.731$ & $\mathrm{BC}$ \\
\hline Peral-2011 & $22.497 \pm 0.723$ & $\mathrm{BC}$ \\
\hline CIMMYT Pak & $22.496 \pm 0.714$ & $\mathrm{BC}$ \\
\hline Ghouri Hybrid & $21.71 \pm 0.74$ & $\mathrm{BCD}$ \\
\hline 31P41 Hybrid & $19.94 \pm 0.76$ & $\mathrm{CD}$ \\
\hline
\end{tabular}


The infestation was monitored for the first time on 14-Oct-2019 and it was the minimum recorded infestation (zero in all treatments) probably because the crop was under five-leaf stage $\left(V_{5}\right)$ in all treatments. But as the crop raised its level it put a positive impact on armyworm proliferation on all subsequent treatments.

The mean infestation recorded after the $2^{\text {nd }}$ week is given in Graph 4.1 and it shows that mean infestation was maximum on the CIMMYT Pak while it was lowest on the 31P41 Hybrid.

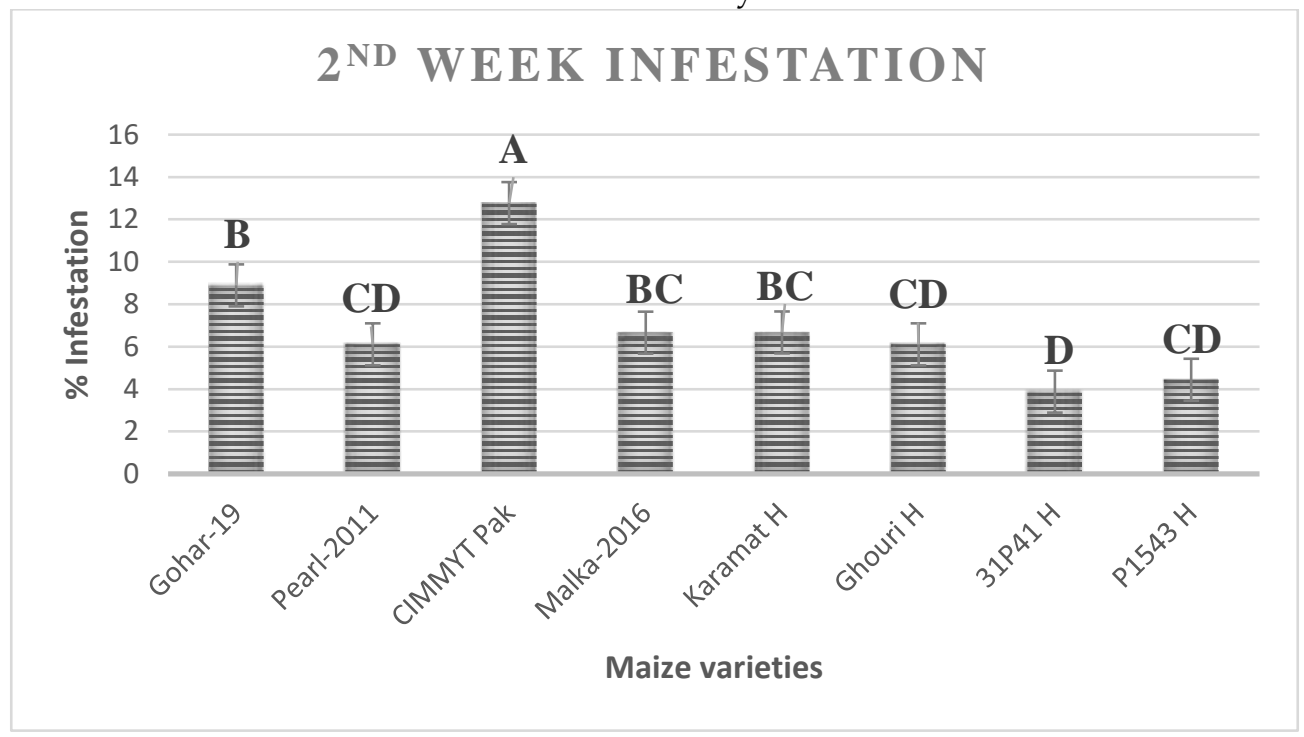

Graph 4.1: Infestation after $2^{\text {nd }}$ week on different maize varieties.

Graph 4.2 is showing infestation recorded after the $3^{\text {rd }}$ week. Statistically, the fall armyworm population was highest on Karamat Hybrid while 31P41 Hybrid showed some sort of tolerance once again. The rise and fall in a population could be determined by variable factors i.e., the infestation rate of FAW is not always the same on different stages of maize crop. It gets varies with the variation in each crop stage. Other than crop development, the abiotic factors like temperature and relative humidity, also determine pest infestation, abundance, and dispersal of insect pests. 


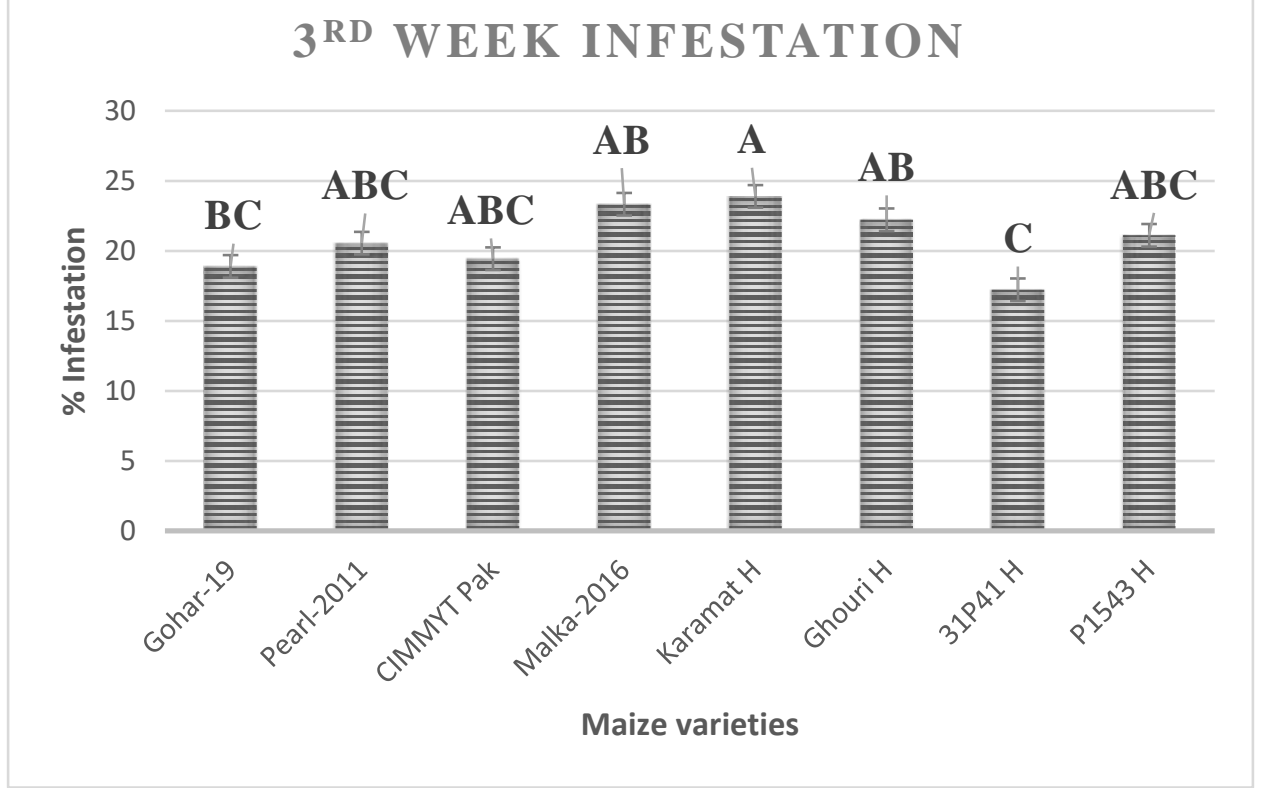

Graph 4.2: Infestation after $3^{\text {rd }}$ week on different maize varieties.

A rise in the mean infestation of the pest in individual experimental units was seen from 28-Oct-2019 to 04-Oct-2019. Malka-2016 showed statistically the highest population of fall armyworm while the least infestation was recorded on 31P41 Hybrid once again.

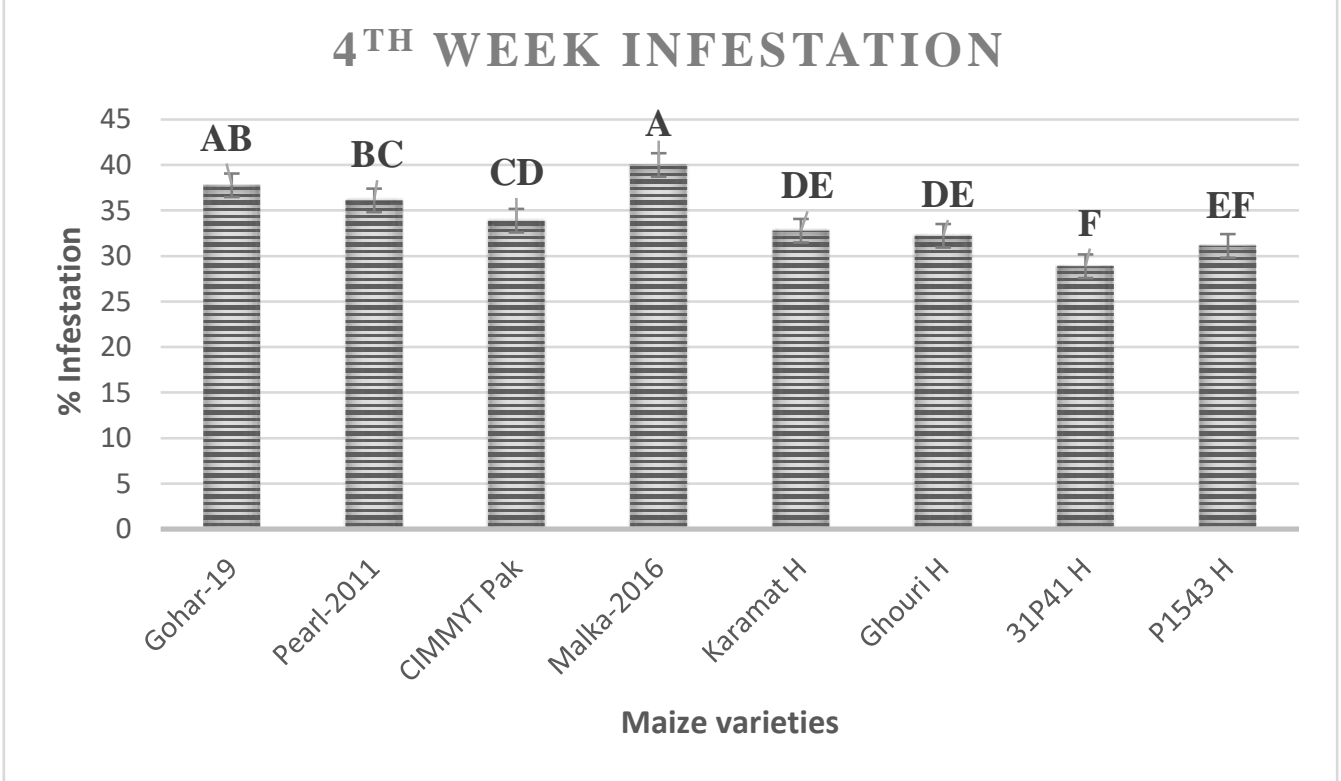

Graph 4.3: Infestation after $4^{\text {th }}$ week on different maize varieties

During the course of studies, the highest population build-up was seen on the $11^{\text {th }}$ of November 2019. All the treatment crops observed peak pest 
population possibly conditions were in favour of FAW. The highest damage of $53.88 \%$ was recorded on Malka-2016. Statistically, no difference was found among the infestation levels recorded on Ghouri Hybrid, 31P41 Hybrid and P1543 Hybrid.

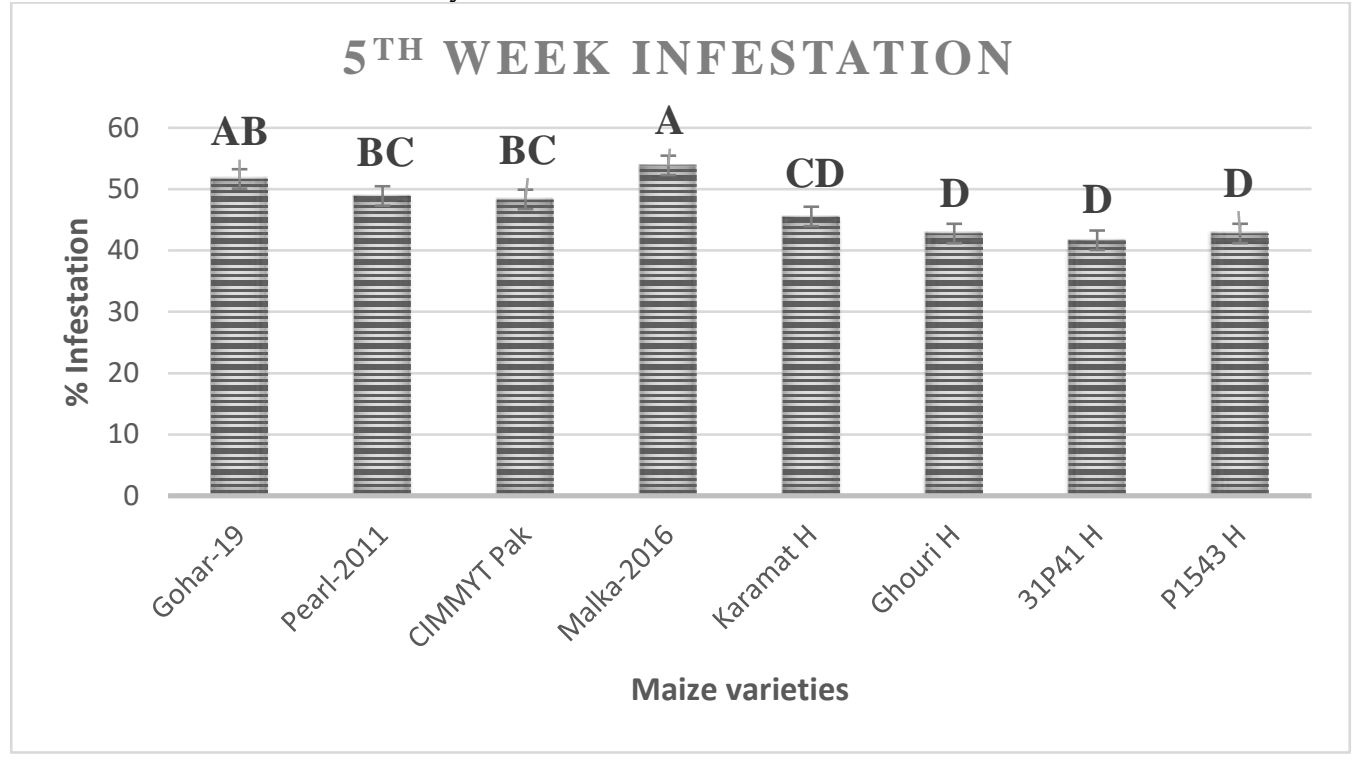

Graph 4.4: Infestation after $5^{\text {th }}$ Week on different Maize Varieties

Inter-varietal infestation after the $6^{\text {th }}$ week shows that Malka-2016 showed significantly highest fall armyworm damage. The levels of invasion recorded on 31P41 Hybrid and P1543 were statistically lowermost than the rest of the treatments.

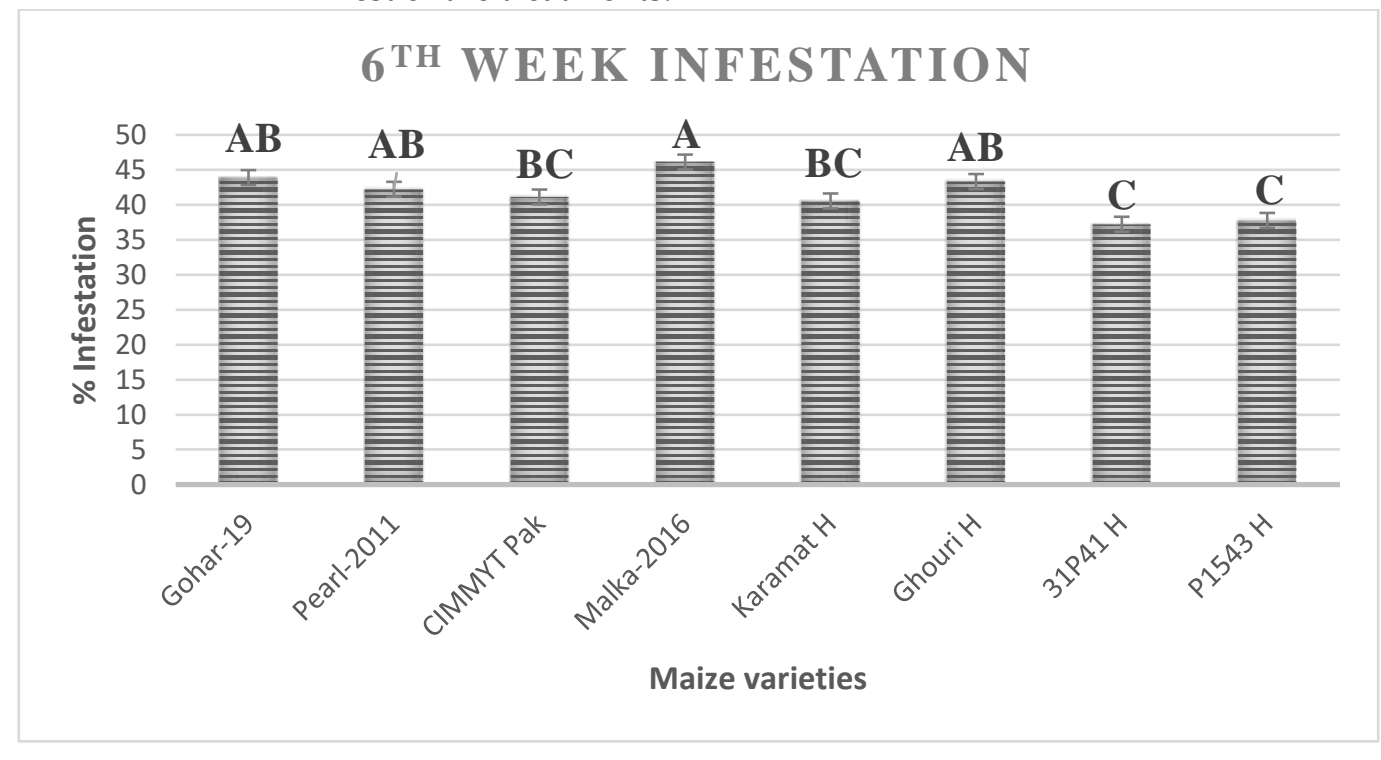

Graph 4.5: Infestation after $6^{\text {th }}$ week on different maize varieties. 
In the very next week, a decline in the population build-up was seen. But, the higher most infestation of fall armyworm was observed again on Malka-2016. P1543 Hybrid showed 25.55\% damage which was the least damage observed in the week.

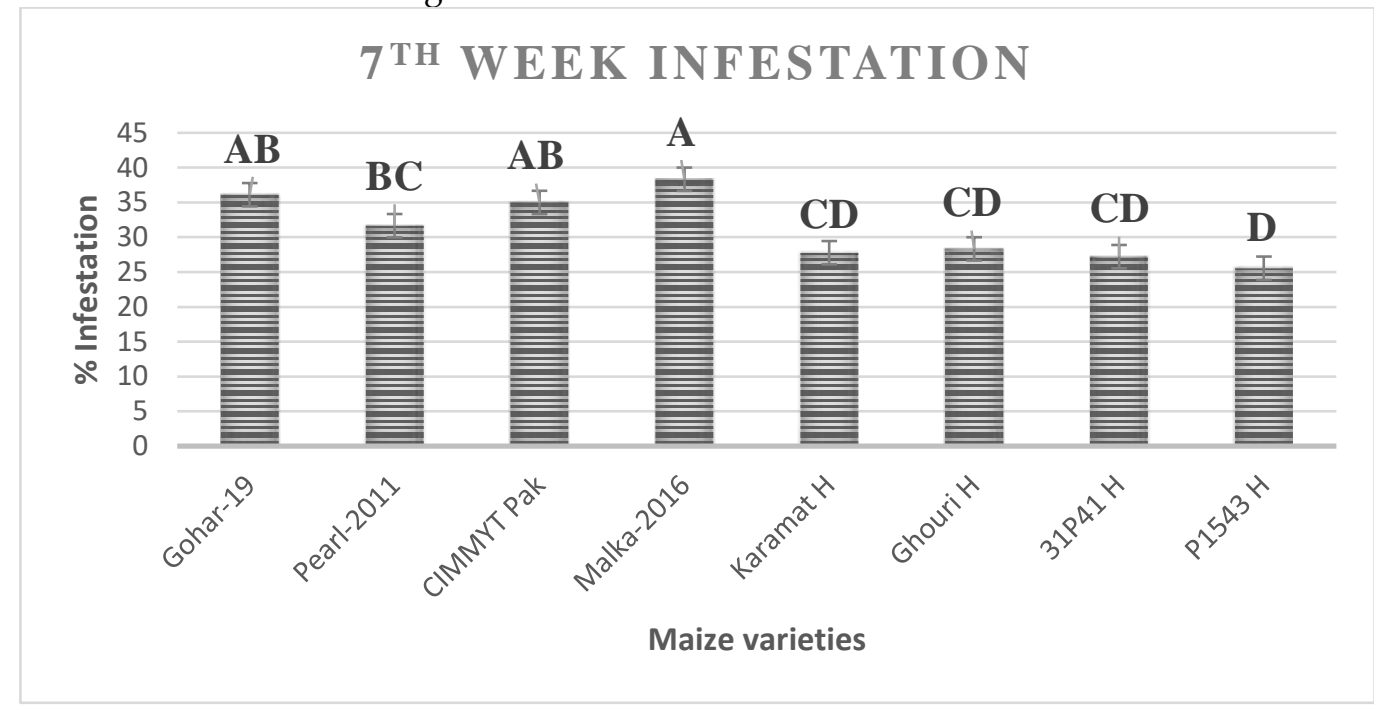

Graph 4.6: Infestation after $7^{\text {th }}$ week on different maize varieties.

The subsequent reduction in the pest occurrence was seen once again after the $8^{\text {th }}$ week of investigation. Graph 4.7 shows the mean infestation recorded on 03-Dec-19. Malka-2016 possessed the highest FAW infestation, 31P41 Hybrid showed some sort of tolerance against the pest and unveiled the lowest invasion.

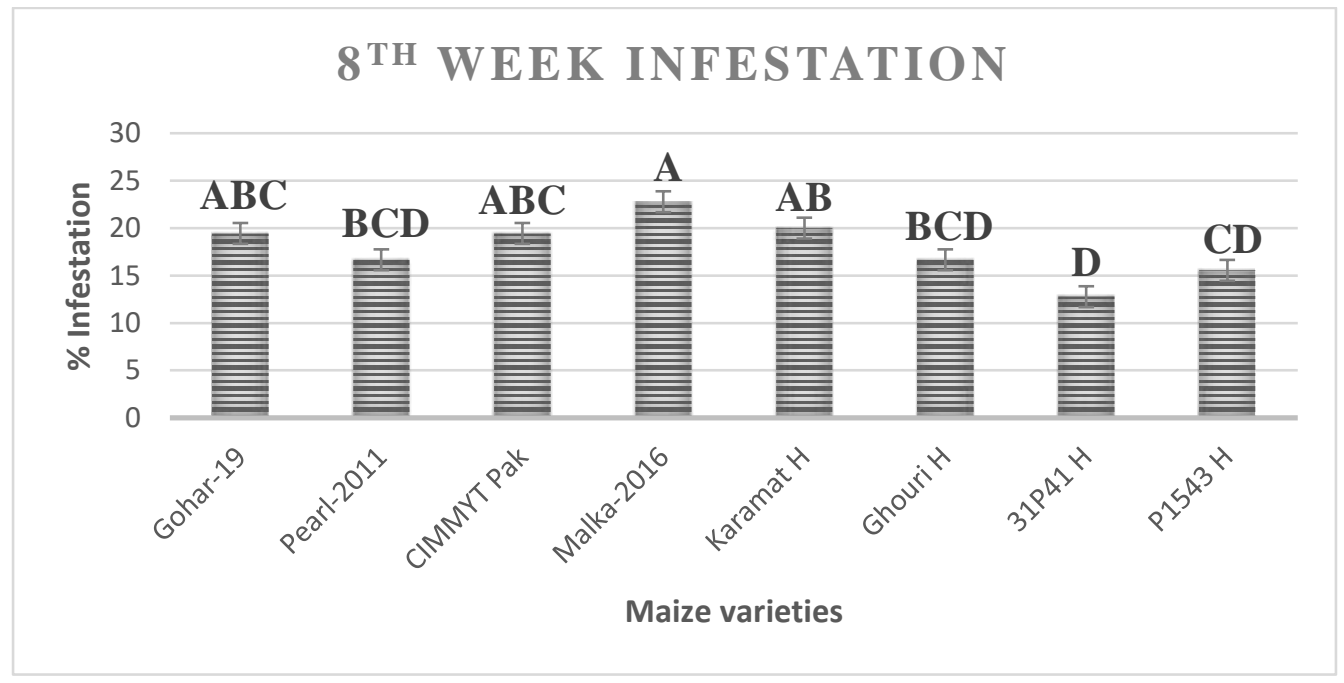

Graph 4.7: Infestation after $8^{\text {th }}$ week on different maize varieties. 
Temperature drop towards in the middle of December negatively influenced the population build-up of fall armyworm. Additionally, crop maturity was another factor that overlapped with temperature to reduce FAW infestation. CIMMYT Pak significantly showed lowermost invasion of the pest on 10-Dec-2019. On the other hand, Malka-2016, Karamat Hybrid and Ghouri Hybrid possessed the same levels of infestation which were highestmost.

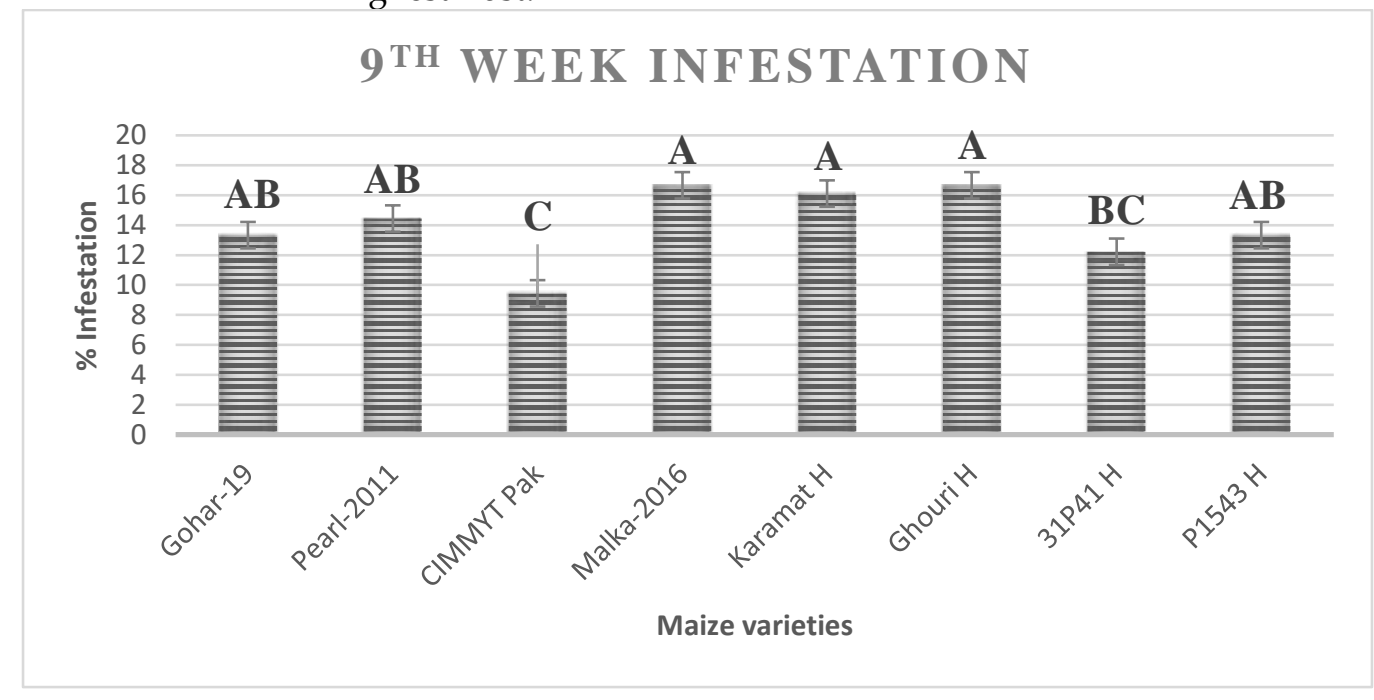

Graph 4.8: Infestation after $9^{\text {th }}$ week on different maize varieties.

Similar to the previous week, invasion recorded on 17-Dec-19 shows a subsequent drop in the pest population. Statistically, Malka-2016, Karamat Hybrid and Ghouri Hybrid showed maximum mean values of pest infestation while CIMMYT Pak showed the lowest infestation in that particular week.

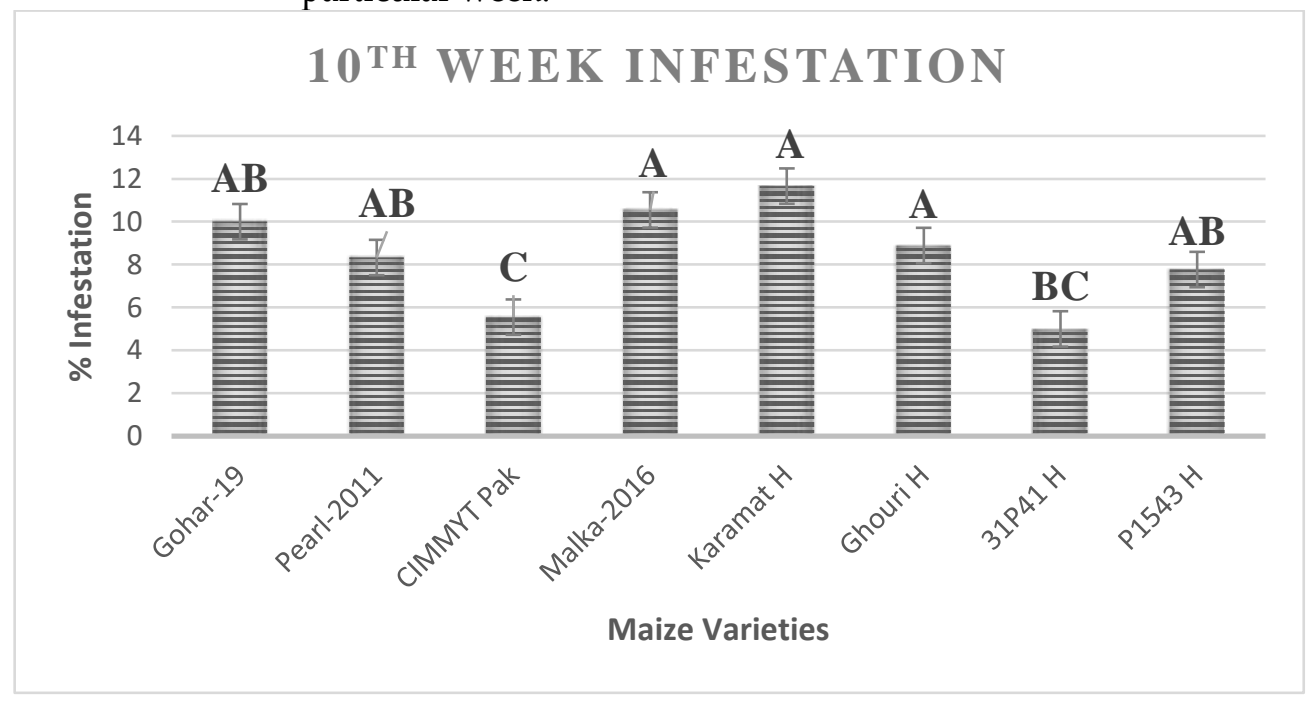

Graph 4.9: Infestation after $10^{\text {th }}$ week on different maize varieties. 
The graphs above showing the periodic variations in the pest infestation from the early days to the maturity of the treatment crops in their respective blocks. They are also showing different susceptibility levels of the different maize varieties.

The Tukey's test on the date wise infestation showed highly significant results (Table 4), it was revealed that infestation was maximum on the $11^{\text {th }}$ of November 2019 followed by $18^{\text {th }}$ of November 2019. No statistical difference was found between the invasion recorded on the $17^{\text {th }}$ and $21^{\text {st }}$ of December 2019. The lowest population of FAW recorded on the $14^{\text {th }}$ of November than 4-Nov-19, 27-Nov-19, 28-Oct-19, 03-Dec-19, and 10-Dec-19.

Table 4. FAW Infestation on Different Dates from Oct-Dec (2019).

\begin{tabular}{|c|c|c|}
\hline Dates & Mean \pm S.E. & Homogenous Groups \\
\hline 11-Nov-2019 & $46.95 \pm 4.95$ & $\mathrm{~A}$ \\
\hline 18-Nov-2019 & $41.53 \pm 5.27$ & B \\
\hline 04-Nov-2019 & $34.1 \pm 5.07$ & C \\
\hline 27-Nov-2019 & $31.25 \pm 4.95$ & $\mathrm{D}$ \\
\hline 28-Oct-2019 & $20.83 \pm 4.09$ & $\mathrm{E}$ \\
\hline 03-Dec-2019 & $17.92 \pm 4.07$ & $\mathrm{~F}$ \\
\hline 10-Dec-2019 & $14.03 \pm 3.97$ & G \\
\hline 17-Dec-2019 & $8.47 \pm 2.03$ & $\mathrm{H}$ \\
\hline 21-Oct-2019 & $6.94 \pm 2.05$ & $\mathrm{H}$ \\
\hline 14-Oct-2019 & $0 \pm 0.5$ & I \\
\hline $\mathbf{P}$ & 0.0000 & $P<0.05$ \\
\hline
\end{tabular}

The periodic infestation on different corn varieties viz., Gohar-19, Pearl11, CIMMYT Pak, Malka-16, Karamat Hybrid, Ghouri Hybrid, 31P41, and P1543 showed a significant and positive correlation with maximum temperature, minimum temperature, and the mean temperature. But the strength of correlation was weak possibly due to cold weather conditions. In contrast to temperature, relative humidity showed a non-significant and negative correlation with pest infestation and its strength was weak also (Table 5).

\section{Discussion:}

Spodoptera frugiperda is a polyphagous armyworm affecting various economically important cash crops worldwide (Silva et al 2017). The FAW infestation level in the present study varied significantly on all different maize varieties. Fall armyworm showed maximum infestation on Malka-16 while the attack on P1543 hybrid was limited. In general, conventional maize 
varieties were susceptible to fall armyworm damage while hybrids showed some sort of tolerance to attack. In a similar study in Eastern Zimbabwe, Baudron et al (2019) visualized different agronomic practices against the invasion of fall armyworm. They inspected a total of 791 maize fields of small landowners and interviewed the farming communities. It was concluded at the end: the cropping areas that strictly followed weeding activity; less likely attacked by fall armyworm, pumpkin intercropping increased the risk of damage, even certain high-yielding maize varieties were found susceptible to the pest.

Planting a diverse range of crops on-farm support the proliferation of natural enemies and reduces the incidence of FAW. The females of $S$. frugiperda prefer to lay their eggs on maize plants, the maize monoculture provides a sea of maize plants with no diversity, hence it increases the incidence of FAW attack. When maize is intercropped with a diverse range of crops, less feeding is observed with fewer eggs laying on the maize crop (FAO 2018).

Similarly, significant variation in FAW infestation was seen during different weeks ranging from 14-Oct-2019 to 17-dec-2019 possibly due to different growth stages of crops and weather factors i.e., temperature and humidity. Considerably higher populations of the pest were observed on different dates during the $1^{\text {st }}$ half of November 2019. Perhaps the cropping stage favoured its infestation because FAW develops more rapidly on the growth stages of maize crop rather than reproductive stages (Barfield \& Ashley 1987). It could be due to favourable temperature and humidity. From December to onward infestation showed a decline possibly due to cold weather conditions.

The analysis of correlation with weather factors and the pest infestation showed a very weak strength of correlation probably due to a drop in temperature abruptly. The population correlation with maximum, mean and minimum temperatures were weak but positive $(r=0.139, r=0.149$ and $r=$ 0.159 , respectively) whereas relative humidity showed a negative but weak relation $(r=-0.104)$ with infestation. Nagoshi \& Meagher (2004) studied seasonal fluctuations in populations of fall armyworm and they detected the peak populations of $S$. frugiperda twice a year; during spring (March-May) and fall (October-December). Early planting and cold weather conditions could be the possible reasons for the pest decline in December 2019 in the current research work.

The results in the present investigation enlightened that in the first five weeks from 14-Oct to 11 Nov 2019 infestation on different maize varieties attained maximum values: the temperature fluctuated between $25-30{ }^{\circ} \mathrm{C}$ while relative humidity remained inside the range of $45-55 \%$ during the phase of population build-up. But later on, an abrupt fall in temperature caused the population build-up to decline. In the studies of Valdez-Torres et al (2012) and Simmons (1993), it was revealed, FAW showed maximum fecundity, reproduction, growth and development in the temperature range of 22-32 ${ }^{\circ} \mathrm{C}$. In our study, the response of fall armyworm remained parallel to 
the findings of Valdez-Torres et al (2012) and Simmons (1993), until there was a decline in temperature.

\section{References}

1. Aasman, K (2001) Effect of temperature on development and activity of maize stem borer Chilo partellus. Bull Environ Ent 125-127. https://doi.org/10.1017/S0007485314000601

2. Abid M, Scheffran J, Schneider UA, Elahi E (2019) Farmer perceptions of climate change observed trends and adaptation of agriculture in Pakistan. Environ manag 63(1):110-123. https://doi.org/10.1007/s00267-018-1113-7

3. Ahmad T, Hassan MW, Jamil M, Iqbal J (2016) Population Dynamics of Aphids (Hemiptera: Aphididae) on Wheat Varieties (Triticum aestivum L.) as Affected by Abiotic Conditions in Bahawalpur, Pakistan. Pakistan J Zool 48(4):1039-1044

4. Akutse KS, Kimemia JW, Ekesi S, Khamis FM, Ombura OL, Subramanian S (2019) Ovicidal effects of entomopathogenic fungal isolates on the invasive fall armyworm Spodoptera frugiperda (Lepidoptera: Noctuidae). J Appl Entomol 143:626-663. https://onlinelibrary.wiley.com/doi/abs/10.1111/jen.12634

5. Barfield CS, Ashley TR (1987) Effects of Corn Phenology and Temperature on the Life cycle of the Fall Armyworm, Spodoptera frugiperda (Lepidoptera: Noctuidae). Fla Entomol 70(1):110-116. https://doi.org/10.2307/3495097

6. Baudron F, Zaman-Allah MA, Chaipa I, Chari N, Chinwada P (2019) Understanding the Factors Influencing Fall Armyworm (Spodoptera frugiperda JE Smith) Damage in African Smallholder Maize Fields and Quantifying its Impact on Yield. A case study in Eastern Zimbabwe. Crop Prot 120:141-150. https://doi.org/10.1016/j.cropro.2019.01.028

7. Briere JF, Pracros P, Le Roux AY, Pierre JS (1999) A Novel Rate Model of Temperature-dependent Development for Arthropods. Environ Entomol 28(1):22-29. https://doi.org/10.1093/ee/28.1.22

8. Britannica (2017) Population Ecology. https://www.britannica.com/science/populationecology/Logistic-population-growth\#ref588061. Accessed 13 July 2020

9. FAO (2018) Integrated Management of the Fall Armyworm on Maize. http://www.fao.org/3/I8665EN/i8665en.pdf. Accessed 05 May 2020

10. Fuxa JR, Richter AR, Acudelo-Silva, F (1988) Effect of Host Age and Nematode Strain on Susceptibility of Spodoptera frugiperda to Steinernema feltiae. J Nematol 20(1):91

11. Guarneri AA, Lazzari C, Diotaiuti L, Lorenzo MG (2002) The Effect of Relative Humidity on the Behaviour and Development of Triatoma brasiliensis. Physiol Entomol 27(2):142-147. https://onlinelibrary.wiley.com/doi/abs/10.1046/j.1365-3032.2002.00279.x

12. Kamata N (2000) Population dynamics of the beech caterpillar, Syntypistis punctatella, and biotic and abiotic factors. Population $\quad$ Ecol 42(3):267-278. https:/esjjournals.onlinelibrary.wiley.com/doi/abs/10.1007/PL00012005

13. Kasoma C, Shimelis H, Laing M, Shayanowako A I, Mathew I (2020) Screening of inbred lines of tropical maize for resistance to fall armyworm, and for yield and yield-related traits. Crop Prot 105218. https://doi.org/10.1016/j.cropro.2020.105218

14. Lu Y, Wu K (2011) Effect of Relative Humidity on Population Growth of Apolygus lucorum (Heteroptera: Miridae). Appl Entomol Zool 46(3):421-427. https://doi.org/10.1007/s13355-011-0058-6

15. Mashwani AM, Ullah F, Sattar S, Ahmand S, Khan MA (2011) Efficacy of different Insecticides against Maize Stem Borer, Chilo partellus Swinhoe (Lepidoptera: Pyralidae) at Peshawar and Swat Valleys of Khyber Pakhutunkhwa, Pakistan. Sarhad J Agric 27(3):459-465

16. Montezano DG, Specht A, Sosa-Gómez DR, Roque-Specht VF, Sousa-Silva JC, Paula-Moraes SV, Peterson JA, Hunt TE (2018) Host plants of Spodoptera frugiperda (Lepidoptera: Noctuidae) in the Americas. Afr Entomol 26:286-300. https://doi.org/10.4001/003.026.0286 
17. Naeem-Ullah, U, Ansari, MA, Iqbal N, Saeed S (2019) First Authentic Report of Spodoptera frugiperda (J.E. Smith) (Noctuidae: Lepidoptera) an Alien Invasive Species from Pakistan. Appl Sci Bus Econ 6(1):1-3

18. Nagoshi RN, Meagher RL (2004) Seasonal Distribution of Fall Armyworm (Lepidoptera: Noctuidae) Host Strains in Agricultural and Turf Grass Habitats. Environ Entomol 33(4):881-889. https://doi.org/10.1603/0046-225X-33.4.881

19. Shipp JL, Zhang Y, Hunt DWA, Ferguson G (2003) Influence of Humidity and Greenhouse Microclimate on the Efficacy of Beauveria bassiana (Balsamo) for Control of Greenhouse Arthropod Pests. Environ Entomol 32(5):1154-1163. https://doi.org/10.1603/0046-225X-32.5.1154

20. Silva DMD, Bueno ADF, Andrade K, Stecca CDS, Neves PMOJ, Oliveira MCND (2017) Biology and nutrition of Spodoptera frugiperda (Lepidoptera: Noctuidae) fed on different food sources. Sci Agri 74(1):18-31. https://doi.org/10.1590/1678-992x-2015-0160

21. Simmons AM (1993) Effects of Constant and Fluctuating Temperatures and Humidities on the Survival of Spodoptera frugiperda Pupae (Lepidoptera: Noctuidae). Fla Entomol 76(2):333-340. https://doi.org/10.2307/3495733

22. Valdez-Torres JB, Soto-Landeros F, Osuna-Enciso T, Báez-Sañudo MA (2012) Modelos de Predicción Fenológica para Maíz Blanco (Zea mays L.) y Gusano Cogollero (Spodoptera frugiperda JE Smith). Agrociencia 46(4):399-410

23. Wallner WE (1987) Factors affecting insect population dynamics: differences between outbreak and $\begin{array}{lllll}\text { non-outbreak } \quad \text { species. } & \text { Ann }\end{array}$ https://doi.org/10.1146/annurev.en.32.010187.001533 
Table 5. Effect of meteorological factors (Pearson Correlation= r) on population dynamics of FAW (Noctuidae: Lepidoptera) along with different maize varieties and different times.

\section{Weather factors $\quad$ FAW (Mean \pm S.E.) on maize varieties and correlation with weather factors}

\begin{tabular}{|c|c|c|c|c|c|c|c|c|c|c|c|c|}
\hline Date & Max T. & $\begin{array}{c}\text { Mean } \\
\text { T. }\end{array}$ & $\operatorname{Min} \mathrm{T}$. & \% R.H. & $\begin{array}{c}\text { Gohar- } \\
19\end{array}$ & $\begin{array}{c}\text { Pearl- } \\
2011\end{array}$ & $\begin{array}{c}\text { CIMMYT } \\
\text { Pak }\end{array}$ & $\begin{array}{c}\text { Malka- } \\
2016\end{array}$ & $\begin{array}{c}\text { Karamat } \\
\text { H. }\end{array}$ & $\begin{array}{c}\text { Ghouri } \\
\text { H. }\end{array}$ & $\begin{array}{c}\text { 31P41 } \\
\text { H. }\end{array}$ & $\begin{array}{c}\text { P1543 } \\
\text { H. }\end{array}$ \\
\hline 14/Oct/19 & 31.28 & 26.78 & 22.28 & 45 & $0 \pm 0.75$ & $0 \pm 0.77$ & $0 \pm 0.70$ & $0 \pm 0.75$ & $0 \pm 0.80$ & $0 \pm 0.80$ & $0 \pm 0.85$ & $0 \pm 0.80$ \\
\hline 21/ Oct /19 & 31.85 & 27.28 & 22.71 & 48.85 & $\begin{array}{c}8.89 \pm \\
0.91\end{array}$ & $\begin{array}{c}6.11 \pm \\
0.94\end{array}$ & $12.77 \pm 0.98$ & $\begin{array}{c}6.66 \pm \\
0.85\end{array}$ & $6.67 \pm 0.88$ & $\begin{array}{c}6.11 \pm \\
0.94\end{array}$ & $\begin{array}{c}3.88 \pm \\
0.90\end{array}$ & $\begin{array}{c}4.44 \pm \\
0.81\end{array}$ \\
\hline 28/ Oct /19 & 32.15 & 27.51 & 22.87 & 49.28 & $\begin{array}{c}18.89 \pm \\
1.0\end{array}$ & $\begin{array}{c}20.55 \pm \\
0.99\end{array}$ & $19.44 \pm 0.86$ & $\begin{array}{c}23.33 \pm \\
0.80\end{array}$ & $\begin{array}{c}23.89 \pm \\
0.77\end{array}$ & $\begin{array}{c}22.22 \pm \\
1.0\end{array}$ & $\begin{array}{c}17.22 \pm \\
0.89\end{array}$ & $\begin{array}{c}21.11 \pm \\
1.0\end{array}$ \\
\hline 04/Nov/19 & 31.95 & 27.05 & 22.15 & 52.57 & $\begin{array}{c}37.77 \pm \\
1.3\end{array}$ & $\begin{array}{c}36.11 \pm \\
0.80\end{array}$ & $33.88 \pm 1.02$ & $40 \pm 1.0$ & $\begin{array}{c}32.78 \pm \\
1.12\end{array}$ & $\begin{array}{c}32.22 \pm \\
1.0\end{array}$ & $\begin{array}{c}28.88 \pm \\
1.02\end{array}$ & $\begin{array}{c}31.11 \pm \\
0.99\end{array}$ \\
\hline 11/ Nov /19 & 28.47 & 25.02 & 21.57 & 54.14 & $\begin{array}{c}51.67 \pm \\
1.23\end{array}$ & $\begin{array}{c}48.89 \pm \\
1.51\end{array}$ & $48.33 \pm 1.57$ & $\begin{array}{c}53.88 \pm \\
1.12\end{array}$ & $45.55 \pm 1.5$ & $\begin{array}{c}42.77 \pm \\
1.1\end{array}$ & $\begin{array}{c}41.67 \pm \\
1.45\end{array}$ & $\begin{array}{c}42.77 \pm \\
1.5\end{array}$ \\
\hline 18/ Nov /19 & 26.44 & 22.075 & 17.71 & 58.75 & $\begin{array}{c}43.89 \pm \\
1.11\end{array}$ & $\begin{array}{c}42.22 \pm \\
1.48\end{array}$ & $41.11 \pm 1.39$ & $\begin{array}{c}46.11 \pm \\
1.2\end{array}$ & $40.55 \pm 1.3$ & $\begin{array}{c}43.33 \pm \\
1.17\end{array}$ & $\begin{array}{c}37.22 \pm \\
1.22\end{array}$ & $\begin{array}{c}37.77 \pm \\
0.93\end{array}$ \\
\hline 27/ Nov/19 & 25.12 & 20.485 & 15.85 & 61.14 & $\begin{array}{c}36.11 \pm \\
1.4\end{array}$ & $\begin{array}{c}31.66 \pm \\
1.5\end{array}$ & $35 \pm 1.3$ & $\begin{array}{c}38.33 \pm \\
1.32\end{array}$ & $\begin{array}{c}27.78 \pm \\
1.12\end{array}$ & $\begin{array}{c}28.33 \pm \\
1.22\end{array}$ & $\begin{array}{c}27.22 \pm \\
1.23\end{array}$ & $\begin{array}{c}25.55 \pm \\
1.38\end{array}$ \\
\hline 03/Dec/19 & 23.75 & 19.015 & 14.28 & 63.57 & $\begin{array}{c}19.44 \pm \\
1.36\end{array}$ & $\begin{array}{c}16.66 \pm \\
1.11\end{array}$ & $19.44 \pm 1.16$ & $\begin{array}{c}22.78 \pm \\
1.02\end{array}$ & $20 \pm 1.5$ & $\begin{array}{c}16.66 \pm \\
1.14\end{array}$ & $\begin{array}{c}12.77 \pm \\
1.13\end{array}$ & $\begin{array}{c}15.55 \pm \\
1.05\end{array}$ \\
\hline 10/Dec/19 & 21.43 & 16.925 & 12.42 & 72.15 & $\begin{array}{c}13.33 \pm \\
0.97\end{array}$ & $\begin{array}{c}14.44 \pm \\
0.86\end{array}$ & $9.44 \pm 0.86$ & $\begin{array}{c}16.66 \pm \\
0.84\end{array}$ & $\begin{array}{c}16.11 \pm \\
0.89\end{array}$ & $\begin{array}{c}16.66 \pm \\
0.75\end{array}$ & $\begin{array}{c}12.22 \pm \\
0.88\end{array}$ & $\begin{array}{c}13.33 \pm \\
0.89\end{array}$ \\
\hline
\end{tabular}




\begin{tabular}{|c|c|c|c|c|c|c|c|c|c|c|c|c|}
\hline 17/Dec/19 & 15.57 & 12.925 & 10.28 & 84.28 & $\begin{array}{l}10 \pm \\
0.90\end{array}$ & $\begin{array}{c}8.33 \pm \\
0.82\end{array}$ & $5.55 \pm 0.85$ & $\begin{array}{c}10.55 \pm \\
0.85\end{array}$ & $\begin{array}{c}11.66 \pm \\
0.95\end{array}$ & $\begin{array}{c}8.89 \pm \\
0.86\end{array}$ & $5 \pm 0.75$ & $\begin{array}{c}7.77 \pm \\
0.89\end{array}$ \\
\hline $\begin{array}{l}\text { Temperature } \\
\text { (maximum) }\end{array}$ & & & & & $\begin{array}{c}r= \\
0.1260\end{array}$ & $\begin{array}{c}r= \\
0.1453\end{array}$ & $\mathrm{r}=0.2213$ & $\begin{array}{c}r= \\
0.1076\end{array}$ & $\mathrm{r}=0.0923$ & $\begin{array}{c}r= \\
0.1137\end{array}$ & $\begin{array}{c}r= \\
0.1541\end{array}$ & $\begin{array}{c}r= \\
0.1472\end{array}$ \\
\hline $\begin{array}{c}\text { Temperature } \\
\text { (mean) }\end{array}$ & & & & & $\begin{array}{c}r= \\
0.1379\end{array}$ & $\begin{array}{c}r= \\
0.1571\end{array}$ & $r=0.2306$ & $\begin{array}{c}r= \\
0.1149\end{array}$ & $r=0.1045$ & $\begin{array}{c}r= \\
0.1203\end{array}$ & $\begin{array}{c}r= \\
0.1645\end{array}$ & $\begin{array}{c}r= \\
0.1597\end{array}$ \\
\hline $\begin{array}{c}\text { Temperature } \\
\text { (minimum) }\end{array}$ & & & & & $\begin{array}{c}r= \\
0.1496\end{array}$ & $\begin{array}{c}r= \\
0.1684\end{array}$ & $\mathrm{r}=0.2379$ & $\begin{array}{c}r= \\
0.1216\end{array}$ & $\mathrm{r}=0.1170$ & $\begin{array}{c}r= \\
0.1262\end{array}$ & $\begin{array}{c}r= \\
0.1742\end{array}$ & $\begin{array}{c}r= \\
0.1718\end{array}$ \\
\hline $\begin{array}{l}\text { Relative } \\
\text { humidity }\end{array}$ & & & & & $\begin{array}{c}r=- \\
0.0960\end{array}$ & $\begin{array}{c}r=- \\
0.1079\end{array}$ & $\mathrm{r}=-0.1979$ & $\begin{array}{c}r=- \\
0.0750\end{array}$ & $r=-0.0499$ & $\begin{array}{c}r=- \\
0.0730\end{array}$ & $\begin{array}{c}r= \\
0.1262\end{array}$ & $\begin{array}{c}r=- \\
0.1065\end{array}$ \\
\hline $\begin{array}{c}\text { Overall } \\
\text { correlation } \\
\text { with different } \\
\text { maize } \\
\text { varieties }\end{array}$ & $\begin{array}{c}r= \\
0.1393\end{array}$ & $\begin{array}{c}r= \\
0.1496\end{array}$ & $\begin{array}{c}r= \\
0.1592\end{array}$ & $\begin{array}{c}r=- \\
0.1048\end{array}$ & & & & & & & & \\
\hline
\end{tabular}

